\title{
RESEARCH
}

Open Access

\section{Blocking Connexin-43 mediated hemichannel activity protects against early tubular injury in experimental chronic kidney disease}

Gareth W. Price ${ }^{1}$, Christos E. Chadjichristos ${ }^{2}$, Panagiotis Kavvadas², Sydney C. W. Tang ${ }^{3}$, Wai Han Yiu³, Colin R. Green ${ }^{4}$, Joe A. Potter ${ }^{1}$, Eleftherios Siamantouras ${ }^{1}$, Paul E. Squires ${ }^{1}$ and Claire E. Hills ${ }^{1 *}$

\begin{abstract}
Background: Tubulointerstitial fibrosis represents the key underlying pathology of Chronic Kidney Disease (CKD), yet treatment options remain limited. In this study, we investigated the role of connexin43 (Cx43) hemichannelmediated adenosine triphosphate (ATP) release in purinergic-mediated disassembly of adherens and tight junction complexes in early tubular injury.

Methods: Human primary proximal tubule epithelial cells (hPTECs) and clonal tubular epithelial cells (HK2) were treated with Transforming Growth Factor Beta1 (TGF- $\beta 1) \pm$ apyrase, or ATP $\gamma \mathrm{S}$ for $48 \mathrm{~h}$. For inhibitor studies, cells were co-incubated with Cx43 mimetic Peptide 5, or purinergic receptor antagonists Suramin, A438079 or A804598. Immunoblotting, single-cell force spectroscopy and trans-epithelial electrical resistance assessed protein expression, cell-cell adhesion and paracellular permeability. Carboxyfluorescein uptake and biosensing measured hemichannel activity and real-time ATP release, whilst a heterozygous $\mathrm{C}_{4} 43^{+/-}$mouse model with unilateral ureteral obstruction (UUO) assessed the role of Cx43 in vivo.

Results: Immunohistochemistry of biopsy material from patients with diabetic nephropathy confirmed increased expression of purinergic receptor P2X7. TGF- $\beta 1$ increased CX43 mediated hemichannel activity and ATP release in hPTECs and HK2 cells. The cytokine reduced maximum unbinding forces and reduced cell-cell adhesion, which translated to increased paracellular permeability. Changes were reversed when cells were co-incubated with either Peptide 5 or P2-purinoceptor inhibitors. $\mathrm{C} \times 43^{+-}$mice did not exhibit protein changes associated with early tubular injury in a UUO model of fibrosis.

Conclusion: Data suggest that Cx43 mediated ATP release represents an initial trigger in early tubular injury via its actions on the adherens and tight junction complex. Since Cx43 is highly expressed in nephropathy, it represents a novel target for intervention of tubulointerstitial fibrosis in CKD.
\end{abstract}

Keywords: Chronic kidney disease, Connexins, Hemichannels, ATP, Cell adhesion, Tubular injury

\footnotetext{
* Correspondence: chills@lincoln.ac.uk

'Joseph Banks Laboratories, School of Life Sciences, University of Lincoln, Green Lane, Lincoln, UK

Full list of author information is available at the end of the article
}

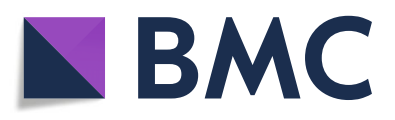

(- The Author(s). 2020 Open Access This article is licensed under a Creative Commons Attribution 4.0 International License, which permits use, sharing, adaptation, distribution and reproduction in any medium or format, as long as you give appropriate credit to the original author(s) and the source, provide a link to the Creative Commons licence, and indicate if changes were made. The images or other third party material in this article are included in the article's Creative Commons licence, unless indicated otherwise in a credit line to the material. If material is not included in the article's Creative Commons licence and your intended use is not permitted by statutory regulation or exceeds the permitted use, you will need to obtain permission directly from the copyright holder. To view a copy of this licence, visit http://creativecommons.org/licenses/by/4.0/. The Creative Commons Public Domain Dedication waiver (http://creativecommons.org/publicdomain/zero/1.0/) applies to the data made available in this article, unless otherwise stated in a credit line to the data. 


\section{Background}

Affecting $10 \%$ of the global population and increasing in prevalence annually, Chronic Kidney Disease (CKD) is a health crisis from which millions die in the absence of a definitive treatment [1]. Individuals are more in danger of CKD if they have any one or more of a number of risk factors including high blood pressure, smoking, established cardiovascular disease and obesity [2]. Characterized by persistent inflammation and fibrosis, tubulointerstitial injury of the proximal region is the key underlying pathology of CKD and develops in response to a number of morphological and phenotypic changes culminating in loss of epithelial stability and increased extracellular matrix deposition [3, 4]. Despite our understanding of these changes, knowledge of the stimuli that initiate activation of resident primary tubular epithelial cells remains limited.

In recent years, trans-membrane proteins called connexins have attracted considerable interest as a potential future target for treatment of multiple disease states [5-8], including various forms of CKD [9]. Connexins assemble into hexameric structures called hemichannels, forming pores in the membrane which directly link the cytoplasm of adjacent cells through the formation of gap junctions [10]. In the absence of cell-cell adhesion, gap junctions fail to form and uncoupled hemichannels allow paracrine release of adenosine triphosphate (ATP) into the local extracellular environment [11].

In $C K D$, diabetic nephropathy accounts for approximately $50 \%$ of patients presenting with end-stage renal failure [1]. Hyperglycemia and downstream changes in connexin expression are critical in the development and progression of secondary micro-vascular complications, [12-15] with glucose decreasing gap junction conductance and disrupting cellular homeostasis in a variety of cell types [16-19]. Evidence that connexin expression is linked to renal damage in CKD [9, 11, 12, 20-24], suggests that they represent a viable therapeutic target for treatment of the disease. Recent studies have confirmed elevated levels of predominant isoform Cx43, in human and rodent models of early renal disease [20,21] whilst the $\mathrm{Cx} 43^{+/-}$unilateral ureteral obstruction (UUO) mouse demonstrates reduced collagen deposition and macrophage infiltration [24]. Work within our group confirmed increased expression of $\mathrm{Cx} 43$ in the tubular region of biopsy material isolated from patients with diabetic nephropathy [11]. Despite increased expression, Transforming Growth Factor Beta, the main pro-fibrotic cytokine linked to tubular injury in both diabetic nephropathy and other forms of CKD [25, 26], reduced gap junction mediated intercellular communication (GJIC) and increased hemichannel mediated ATP release $[11,27]$. With elevated levels of nucleotides and altered connexin expression linked to inflammation and fibrosis in multiple tissue types [28-31], it seems plausible that the loss of GJIC and the subsequent switch to Cx43 mediated hemichannel ATP release in the proximal tubule may be instrumental in facilitating tubular injury.

Loss of E-cadherin (ECAD) mediated cell-cell adhesion is pivotal in initiating a series of phenotypic and morphological events that precede tubulointerstitial fibrosis $[27,32,33]$, with the disassembly of the adherens junction (AJ) and tight junction (TJ) complexes linked to loss of epithelial stability, inflammation, fibrosis and impaired renal function [34, 35]. In the present study, we combine in vivo and in vitro models of CKD to investigate if targeting Cx43 expression and hemichannel activity through genetic and pharmacological blockade, could negate loss of markers linked with tubular injury, ultimately improving function through diminished hemichannel activity, restoration of E-cadherin mediated cell-cell adhesion and reduced paracellular permeability. Using an array of techniques to assess both changes in expression (immunohistochemistry, immunoblotting) and changes in function (e.g. ATP biosensing, single-cell force spectroscopy and trans-epithelial resistance) we demonstrate that increased Cx43 expression and hemichannel mediated ATP release promotes disassembly of adherens and tight junction complexes in human primary proximal tubule epithelial cells and in the UUO mouse model of advanced fibrosis in which the initiating cause is tubulointerstitial inflammation [24, 36]. Blockade of hemichannel mediated ATP release by the Cx43 mimetic Peptide 5, reduces disassembly of the adherens/ tight junction complex and restores epithelial integrity. Importantly, these observations were paralleled in the $\mathrm{Cx} 43^{+/-}$UUO model, where $\mathrm{Cx} 43$ expression is reduced by $50 \%$. Up-regulated in renal tubules of people with diabetic nephropathy (DN) and linked to multiple models of disease and fibrosis [37-40], P2X7 appears instrumental in mediating these ATP driven effects. Together, our study indicates that aberrant $\mathrm{Cx} 43$-mediated ATP release may represent a future therapeutic target in preventing early tubular injury linked to tubulointerstitial fibrosis (TIF) in CKD.

\section{Methods}

\section{Animal model}

Three-month-old SV129 $\mathrm{Cx}_{4} 3^{+/-}$male mice and agematched wild-type littermates $(n=7)$ were generated. Unilateral ureteral obstruction surgery was performed as describe previously [41]. Non-obstructed kidneys were used as controls. Mice were handled in strict accordance with good animal practice, as defined by the relevant national animal welfare bodies of France, and all work was approved by the appropriate committee of the National Institute for Health and Medical Research (INSERM) and the Sorbonne Université (Paris, France). Animals 
were housed at constant temperature with ad libitum access to water and food.

\section{Biopsy staining}

Kidney biopsy slices were obtained from patients with biopsy-proven diabetic nephropathy (DN) (mean age 55; mean diabetes duration: 6.2 yrs.; mean HbA1c: 7.2\%; mean serum creatinine: $464 \mu \mathrm{mol} / \mathrm{L}$; mean proteinuria: $5.80 \mathrm{~g} / 24 \mathrm{~h}, n=10)$. Control renal tissue was obtained from 5 nephrectomy specimens treated for renal carcinoma (mean age 61; mean serum creatinine: $87.8 \mu \mathrm{mol} / \mathrm{L}$, $n=6$ ). As described previously [42], paraffin-embedded renal sections $(4 \mu \mathrm{m})$ were de-paraffinized, rehydrated and subjected to microwave-based antigen retrieval in citric buffer solution $(10 \mathrm{mM})$, followed by quenching in $1 \% \mathrm{H}_{2} \mathrm{O}_{2}$ and blocking in 2\% BSA solution. Sections were stained overnight with anti-P2Y2 (Santa-Cruz, 1: 50), anti-P2Y6 (Novus Biologicals, 1:250) or anti-P2X7 (Novus Biologicals, 1:200) antibodies and subsequently incubated with DAKO EnVision ${ }^{+}$System-HRP antibodies (Dako, Carpinteria, CA). Rabbit IgG was incubated with both DN and control renal sections for isotype-matched negative controls. DAB substrate was used for visualisation and sections were counterstained with hematoxylin. Quantitative analysis was measured by Image-Pro Plus 6.0 and presented as a value of integrated optical density (IOD).

\section{Cell culture and treatment}

Human kidney (HK2) cells (passage 18-30) were maintained in DMEM/Hams F12 medium, supplemented with $10 \% \mathrm{FCS}$ wt/vol, glutamine $(2 \mathrm{mmol} / \mathrm{l})$ and EGF (5 $\mathrm{ng} / \mathrm{ml}$ ), in a humidified atmosphere at $37^{\circ} \mathrm{C}$ with $5 \%$ $\mathrm{CO}_{2}$. Cells are proximal tubular epithelial cells, immortalized by the transduction of human papilloma virus 16 (HPV-16) E6/E7 genes and are mycoplasma-free. For all treatments, cells were seeded in low-glucose DMEM/F12 ( $5 \mathrm{mmol} / \mathrm{L}$ ) for $48 \mathrm{~h}$, then serum-starved overnight prior to treatment with Transforming Growth Factor Beta-1 (TGF- $\beta 1)(2-10 \mathrm{ng} / \mathrm{mL})$ or ATP $\mathrm{AS}(1-100 \mu \mathrm{M})$ for $48 \mathrm{~h}$. For ATP experiments, cells were incubated with either TGF- $\beta 1(10 \mathrm{ng} / \mathrm{mL})$ or ATP $\gamma$ S (100uM) \pm ATP-diphosphohydrolase apyrase (5Units/ml); Suramin $(100 \mu \mathrm{M})$, A438079 $(50 \mu \mathrm{M})$ or A804598 $(50 \mathrm{nM})$ for $48 \mathrm{~h}$.

Primary human proximal tubule epithelial cells (hPTECs) were maintained in the basal medium obtained from the American Type Culture Collection (ATCC), supplemented with the renal epithelial cell growth kit (PCS-400-040) in a humidified atmosphere at $37^{\circ} \mathrm{C}$ with $5 \% \mathrm{CO}_{2}$. Cells were treated with TGF- $\beta 1$ (10 $\mathrm{ng} / \mathrm{mL})+/$ - Peptide $5(25 \mu \mathrm{M})$. A scrambled version was used as a control.

\section{Immunohistochemistry}

Immunohistochemical staining of paraffin-embedded sections $(3 \mu \mathrm{m}$-thick) of mouse renal cortex was performed as described previously [41]. After blocking, sections were incubated with antibodies for $\mathrm{N}$-cadherin (NCAD) (ThermoFischer Scientific, PA5-17526, 1:100) and Zona Occludin-1 (ZO-1) (ThermoFischer Scientific, 61-7300, 1:100), and the Envision detection kit for 30mins at RT (DakoFrance, Trappes, France). Negative controls were obtained by the removal of primary antibodies. The immuno-complex was visualised using DAB substrate and counterstained with hematoxylin.

\section{Total RNA extraction and quantitative real-time PCR}

Total RNA was extracted from renal cortex using TRIzol reagent (Euromedex) RNA quality was checked by control of optical density (OD) at 260 and $280 \mathrm{~nm}$. cDNA was synthesized from $1 \mathrm{mg}$ RNA using the Fermentas $\mathrm{H}$ Minus First-Strand cDNA Synthesis Kit according to the manufacturer's instructions. Quantitative PCR experiments were performed as previously described [24]. Each sample was run in triplicate, and analysis of relative gene expression was done by using the $2^{-\Delta \Delta C T}$ method. Results are expressed in graphs as arbitrary units, which represent the ratio of the target gene to the internal control gene $(H P R T)$. Sequences of primers used in our studies are listed in Table 1.

\section{Western blotting}

Preparation of cytosolic protein from human proximal tubule cells, separation by SDS-gel electrophoresis and transfer onto Immobilon-Fl PVDF membranes have been described previously [43]. Membranes were blocked with Odyssey blocking buffer (LI-COR), then probed with specific polyclonal antibodies against Ecadherin (1:1000), $\mathrm{N}$-cadherin (1:1000), $\beta$-catenin (1: 2000), Claudin-2 (1:500) and ZO-1 (1:1000). Bands were visualized using an OdysseyFC and semi-quantified using ImageStudio (v5.2, LI-COR). Immunoblotting of protein obtained from mouse cortical tissue was performed as above using: E-cadherin (Santa Cruz Biotechnology, sc-7870, 1:500), $\beta$-catenin (BD Transduction Laboratories, 610,154, 1:1000) and Claudin-2 (ThermoFisher Scientific, 32-5600, 1:1000).

Table 1 Forward (FW) and reverse (RV) sequences for primers used in qPCR analysis

\begin{tabular}{ll}
\hline Gene & Sequence \\
\hline P2Y2 & FW: TCAAACCGGCTTATGGGACC \\
& RV: GGCAGCTGAGGTCAAGTGAT \\
P2Y6 & FW: GGGTAGTGTGTGGAGTCGTG \\
& RV: AGCGAGTAGACAGGATGGGT \\
P2X7 & FW: GCACGAATATGGCACCGTC \\
& RV: CCCCACCCTCTGTGACATTC \\
\hline
\end{tabular}




\section{Transepithelial electrical resistance}

Human renal tubule cells were seeded $\left(6 \times 10^{4}\right.$ cells $\left./ \mathrm{ml}\right)$ onto Transwell filters $(12 \mathrm{~mm}$ diameter, pore size $0.4 \mu \mathrm{M}$; Corning, NY) and incubated with TGF- $\beta 1$ (10 $\mathrm{ng} / \mathrm{mL})+/$ - Peptide $5(25 \mu \mathrm{M})$ for $48 \mathrm{~h}$. Scrambled Peptide $5(25 \mu \mathrm{M})$ was used as a control. Transepithelial electrical resistance (TER) was calculated in $\mathrm{ohms} / \mathrm{cm}^{2}$ $\left(' \Omega . \mathrm{cm}^{2}\right)$.

\section{Atomic force microscopy force spectroscopy}

Adhesion was characterised using single-cell force spectroscopy (SCFS), as described previously [44, 45]. Tip-less Arrow TL1 cantilevers (Nanoworld AG, Switzerland) with a low spring constant were used $(0.03$ $\mathrm{N} / \mathrm{m})$. Cantilevers were sterilized with UV (10mins), before being functionalised in poly-L-lysine $(25 \mu \mathrm{g} / \mathrm{ml}$, $30 \mathrm{mins}, \mathrm{RT})$, and fibronectin $\left(20 \mu \mathrm{g} / \mathrm{ml}, 2 \mathrm{~h}, 37^{\circ} \mathrm{C}\right)$. A single cell was captured at the end of the cantilever with a set force $(0.8-1 \mathrm{nN})$ and contact time (8-10s). After attachment, the cell was left to recover for $>5 \mathrm{~min}$, allowing surface binding. The cantilever-attached cell was brought into contact with a substrate cell, until a $1 \mathrm{nN}$ contact force was reached. The two cells were attached for 10s to allow cell-cell adhesion, after which the cantilever was retracted at a constant speed $(5 \mu \mathrm{m} / \mathrm{sec})$. Force-displacement curves were measured until complete detachment (pulling length of 40-90 $\mu \mathrm{m}$ ). Each procedure occurred in triplicate with $45 \mathrm{~s}$ intervals.

\section{Carboxyfluorescein}

HK2 and hPTEC cells were incubated with TGF- $\beta 1$ (10 $\mathrm{ng} / \mathrm{mL}) \pm$ Peptide $5(25 \mu \mathrm{M})$ or Scrambled $(25 \mu \mathrm{M})$ for $48 \mathrm{~h}$. Cells were exposed to $\mathrm{Ca}^{2+}$-free Balanced Salt Solution $(\mathrm{BSS})+$ carboxyfluorescein $(200 \mu \mathrm{M})$ for $10 \mathrm{~min}$ to permit hemichannel-mediated dye uptake, before reapplying $\left[\mathrm{Ca}^{2+}\right]_{\mathrm{e}}$ to close the channels. Images were acquired with a Cool Snap HQ CCD camera (Roper Scientific) and Metamorph software (Universal Imaging Corp., Marlow, Bucks, UK). ImageJ was used to quantify dye uptake, where a region of interest was drawn around each cell (10-15 cells/dish) and mean pixel intensity measured.

\section{ATP biosensing}

ATP-biosensors (Sarissa Biomedical, Coventry UK) were used in simultaneous dual-recording ampomeric mode as described previously [11]. A null sensor accounted for non-specific electro-active artefacts and was subtracted from the ATP trace. Glycerol $(2 \mathrm{mM})$ was included in all solutions. HK2 cells were incubated with TGF- $\beta 1$ (10 $\mathrm{ng} / \mathrm{mL})+/$ - Peptide $5(25 \mu \mathrm{M})$ for $48 \mathrm{~h}$. Cells were transferred to a chamber containing $\mathrm{Ca}^{2+}$-containing BSS perfused at $6 \mathrm{ml} / \mathrm{min}\left(37^{\circ} \mathrm{C}\right)$ and left for $10 \mathrm{~min}$ to acclimatize. $\mathrm{Ca}^{2+}$-free $\mathrm{BSS}$ was used to open hemichannels and $\mathrm{Ca}^{2+}$-containing BSS to close them. Data was calibrated using $10 \mu \mathrm{M}$ ATP. Recordings were acquired at $4 \mathrm{~Hz}$ with a Micro CED (Mark2) interface using Spike software.

\section{Analysis}

Statistical analysis was performed via one-way ANOVA test with Tukey's multiple comparison post-test or t-test. Data are expressed as mean \pm SEM, with ' $n$ ' denoting sample number. A $p$-value $<0.05$ denotes statistical significance.

\section{Results}

TGF- $\beta 1$ regulates expression of adherens and tight junction proteins

Human Kidney proximal tubule epithelial cells were treated with TGF- $\beta 1(2-10 \mathrm{ng} / \mathrm{mL})$ for $48 \mathrm{~h}$. TGF- $\beta 1$ downregulated E-cadherin (ECAD) to $39.7 \pm 5.5 \%$, $37.3 \pm 6.2 \%$ and $38.5 \pm 4.1 \%$ as compared to control, and upregulated $\mathrm{N}$-cadherin (NCAD) to $170.5 \pm 24.7 \%$, $194.2 \pm 15 \%$ and $213.3 \pm 28 \%$ at 2,4 and $10 \mathrm{ng} / \mathrm{mL}$ TGF$\beta 1$ respectively (Fig. $1 \mathrm{a} \&$ b). TGF- $\beta 1$ did not alter $\beta$ catenin expression (Fig. 1c). Expression of the tight junction protein Claudin-2, was reduced to $62.3 \pm 12.2 \%$, $61.6 \pm 4.5 \%$ and $60.5 \pm 4.4 \%$ of control at 2,4 and $10 \mathrm{ng} /$ mL TGF- $\beta 1$ (Fig. 1d), whilst ZO-1 decreased to $67.0 \pm$ $8 \%, 69.2 \pm 1.7 \%$ and $64.8 \pm 4.1 \%$ respectively (Fig. 1e).

\section{ATP $Y S$ regulates adherens and tight junction proteins}

We previously demonstrated that TGF- $\beta 1$ increased hemichannel-mediated ATP release [11]. To determine if ATP mediates changes in adherens and tight junction protein expression, human kidney proximal tubule cells were incubated with ATP $\mathrm{AS}(1-100 \mu \mathrm{M})$ for $48 \mathrm{~h}$. The non-hydrolysable P2-agonist decreased ECAD expression to $87.8 \pm 0.9 \%, 63.8 \pm 1.9 \%$ and $43.4 \pm 6.1 \%$ as compared to control at 1,10 and $100 \mu \mathrm{M} \mathrm{ATP \gamma S}$, and increased NCAD expression to $136.2 \pm 7.6 \%, 158.4 \pm$ $7.3 \%$ and $181.3 \pm 6.3 \%$ respectively (Fig. $2 \mathrm{a} \& \mathrm{~b}$ ). No change in $\beta$-catenin expression was observed (Fig. 2c). ATP $\gamma$ S decreased Claudin-2 to $72.7 \pm 9.8 \%, 61.6 \pm 11.6 \%$ and $42 \pm 2.6 \%$ of control (Fig. 2d) and ZO-1 to $83.7 \pm$ $11.4 \%, 73 \pm 1.8 \%$ and $45.9 \pm 1.4 \%$ (Fig. 2 e) at 1,10 and $100 \mu \mathrm{M}$ respectively.

\section{ATP is downstream of TGF- $\beta 1$ in regulating expression of adherens junction proteins}

To delineate a downstream role for ATP, human proximal renal tubule cells were incubated with TGF- $\beta 1$ (10 $\mathrm{ng} / \mathrm{mL}) \pm$ apyrase $(5 \mathrm{U} / \mathrm{ml})$ for $48 \mathrm{~h}$. As expected, TGF$\beta 1(10 \mathrm{ng} / \mathrm{mL})$ decreased ECAD expression to $20.9 \pm$ $1.4 \%$, whilst co-incubation with apyrase partially restored expression (51.2 $\pm 3.2 \%$, Fig. 3a). Apyrase reduced the TGF- $\beta 1$ evoked increase in NCAD from $191.1 \pm 12.6 \%$ 


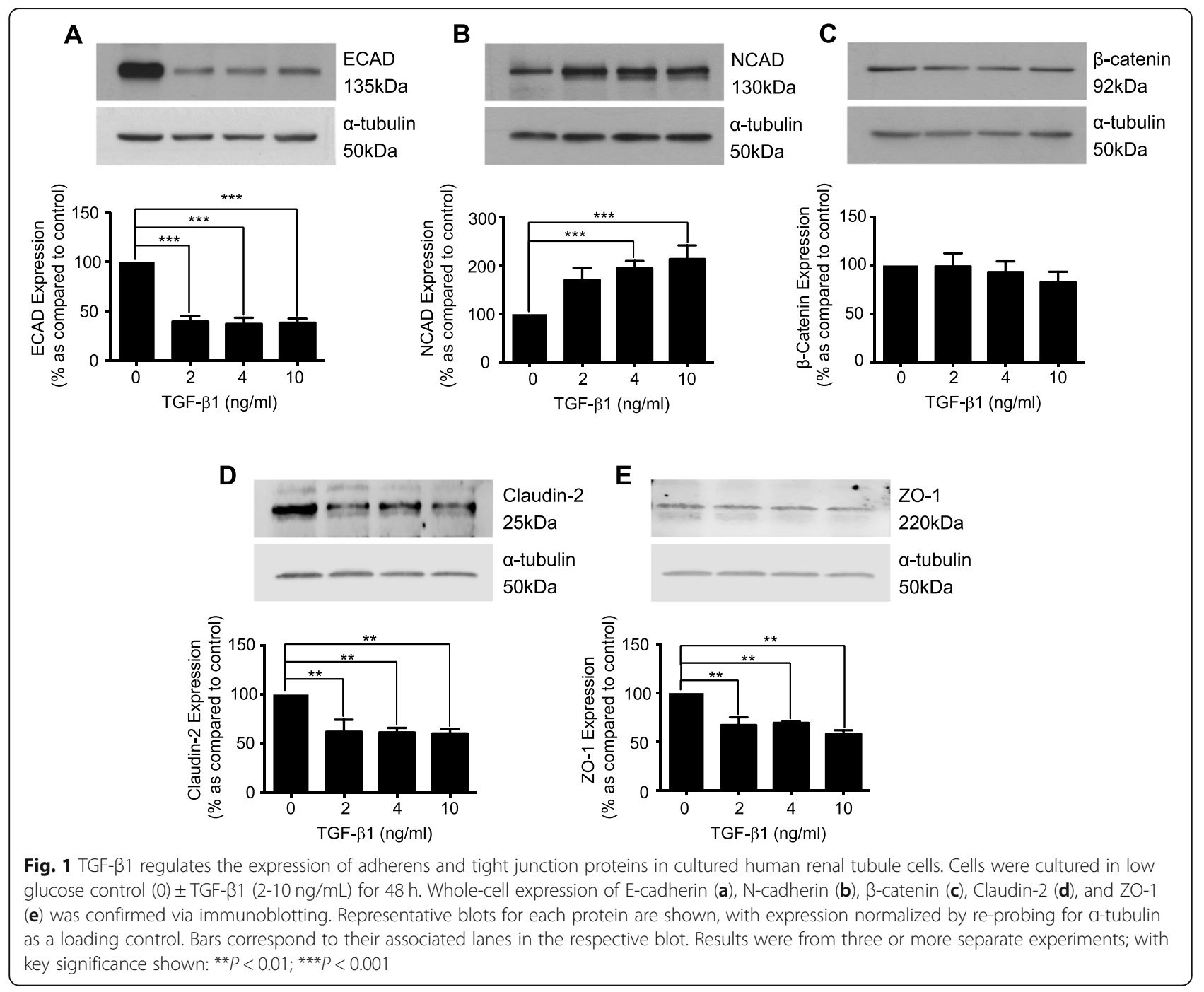

to $133.3 \pm 9.1 \%$, as compared to control (Fig. 3b). TGF$\beta 1$ failed to significantly change $\beta$-catenin expression (Fig. 3c).

Our previous work confirmed that TGF- $\beta 1$ reduces Ecadherin mediated adhesion in human renal tubule cells [11]. On this basis, we assessed the effect of ATP on cellto-cell tethering. A single cell $( \pm 100 \mu \mathrm{M} \mathrm{ATP} \gamma \mathrm{S}, 48 \mathrm{~h})$ was attached to a tip-less cantilever (probe cell) and brought into contact with a substrate cell (Fig. 3d). The two cells were attached with fixed force $(1 \mathrm{nN})$ and contact time (10s) after which the probe cell was retracted. Force versus displacement was recorded continuously. The zero axis represents the baseline in which the two cells were completely detached, whilst the lowest negative point below the baseline represents maximum unbinding force $\left(\mathrm{F}_{\max }\right)$. Analysis determined a reduction in the mean unbinding forces between cells treated with ATP $\gamma$ S (Fig. 3d \& f) from $1.836 \mathrm{nN}+/-0.055$ to $1.279 \mathrm{nN}+/-0.064$. Furthermore, a reduction in force variability occurs (Fig. 3e).
Apyrase failed to negate TGF- $\beta 1$-evoked changes in tight junction protein expression. As expected, TGF- $\beta 1$ $(10 \mathrm{ng} / \mathrm{mL})$ reduced expression of Claudin-2 (Fig. 3g) and ZO-1 (Fig. 3h) to $48.6 \pm 11.3 \%$ and $9.5 \pm 4 \%$ respectively, compared to the control. Co-incubation with apyrase failed to negate this reduction, with expression remaining at $33.3 \pm 4.9 \%$ and $9.5 \pm 3.5 \%$ for Claudin- 2 and ZO-1 respectively. Trans-epithelial electrical resistance (TER) confirmed loss of tight junction function in cells cultured with TGF- $\beta 1(10 \mathrm{ng} / \mathrm{mL})$ or ATP $\gamma$ S $(100 \mu \mathrm{M})$ for $48 \mathrm{~h}$. TER confirmed that TGF- $\beta 1$ and ATP $Y$ S decreased epithelial resistance from $67.7 \pm$ $5.5 \Omega . \mathrm{cm}^{2}$ to $27.6 \pm 2 \Omega . \mathrm{cm}^{2}$ and $42.6 \pm 3 \Omega . \mathrm{cm}^{2}$ respectively (Fig. 3i).

Purinoreceptor, $\mathrm{P} 2 \mathrm{X7}$, exhibits increased expression in our in vitro and in vivo models of disease

Immunohistochemistry of purinoreceptor isoforms P2Y2, P2Y6 and P2X7 (Fig. 4) in biopsy material isolated 


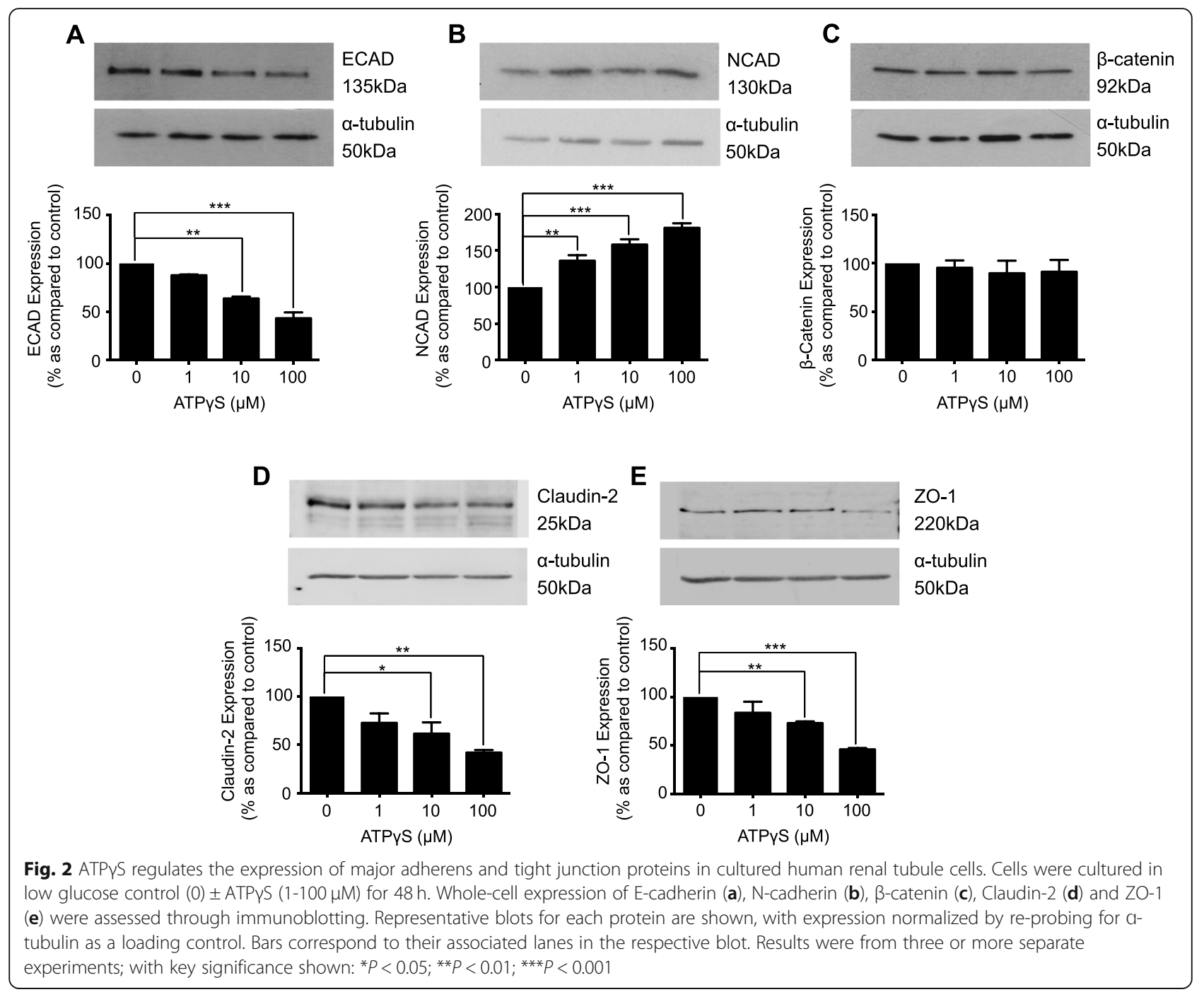

from people with and without DN confirmed upregulation of P2Y2 (Fig. 4a \& b) (IOD: 63,120 \pm 9485 versus $39,400 \pm 142$ for control, Fig. 4c \& d), with a decrease in P2Y6 (Fig. 4f \& g) (IOD: 54,850 \pm 2337 versus 73,170 \pm 574 for control, Fig. 4h \& i). P2X7 expression was significantly increased (Fig. 4k \& l) (IOD: 16,130 \pm 2715 compared to $4013 \pm 62$, for control; Fig. $4 m \& n$ ).

To confirm if TGF- $\beta 1$ regulates purinoreceptor expression in vitro, cells were incubated with TGF- $\beta 1$ (2$10 \mathrm{ng} / \mathrm{mL}$ ) for $48 \mathrm{~h}$. TGF- $\beta 1$ failed to significantly change P2Y2 expression (Fig. 4p) yet a significant downregulation of $\mathrm{P} 2 \mathrm{Y} 6$ to $54.1 \pm 8.8 \%, 49.8 \pm 2.8 \%$ and $36.6 \pm 2.5 \%$ at 2,4 and $10 \mathrm{ng} / \mathrm{mL}$ TGF- $\beta 1$ respectively was observed (Fig. 4q). In contrast, a significant increase in P2X7 was observed at 2,4 and $10 \mathrm{ng} / \mathrm{mL}$ TGF- $\beta 1$ $(206.4 \pm 18.7 \%, 313.3 \pm 29.9 \%$ and $389.1 \pm 6.2 \%$ respectively, Fig. 4r).

Lastly, quantitative PCR experiments confirmed that purinergic receptor expression in tubules isolated from the UUO mouse model exhibit a similar pattern of expression to that observed in human biopsy material and in our TGF- $\beta 1$ treated cells. qRT-PCR of purinoreceptor isoforms P2Y2, P2Y6 and P2X7 (Fig. 4s-u) confirmed upregulation of P2Y2 (Fig. 4s) (0.68 \pm 0.16 to $1.1+/-$ $0.11)$, with a decrease in P2Y6 (Fig. 4t) $(15.0 \pm 0.86$ to $7.2 \pm 0.97$ ) and a significant increase in P2X7 (Fig. 4u) expression (1.3 \pm 0.15 to $6.3 \pm 0.25)$ as compared to WT control.

\section{Blocking P2X7 negates TGF- $\beta 1$-evoked changes in adherens \& tight junction proteins}

Purinergic receptor P2X7, has been linked to fibrosis in multiple disease states [37-40]. Given the statistically significant increase in P2X7 expression in both human biopsy material and in our UUO mouse, the pathophysiological role of P2X7 in mediating the downstream effects of ATP induced tubular injury in our model system were investigated. 


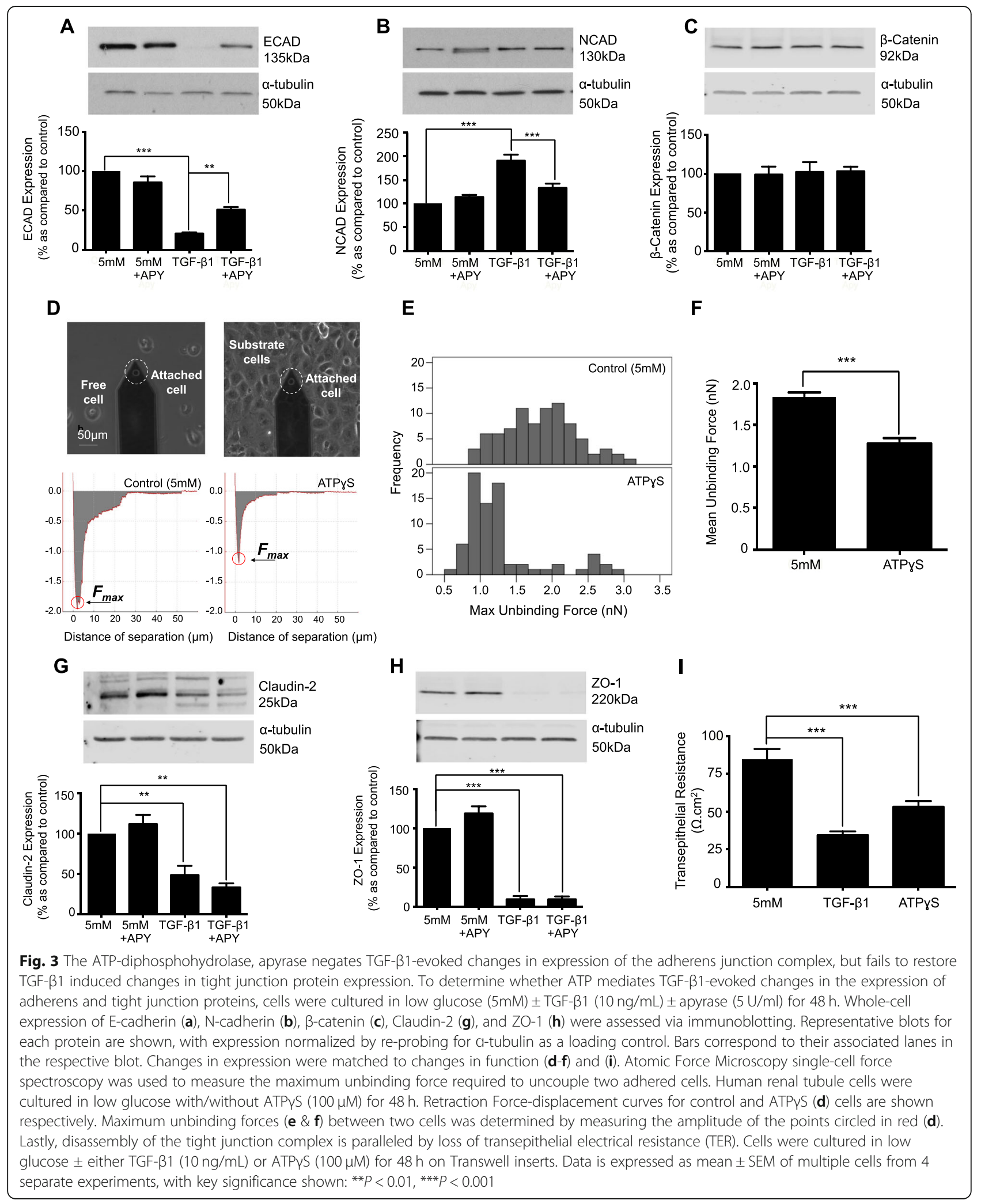

To determine if TGF- $\beta 1$ evoked changes in hemichannel mediated ATP release, facilitates its effects via activation of P2X7, HK2 cells were treated with TGF- $\beta 1 \pm$
Suramin $(100 \mu \mathrm{M})$ or P2X7-specific inhibitors A438079 $(50 \mu \mathrm{M})$ or A804598 (50 nM). The TGF- $\beta 1$-evoked loss in ECAD expression (Fig. 5a), was partly restored, from 


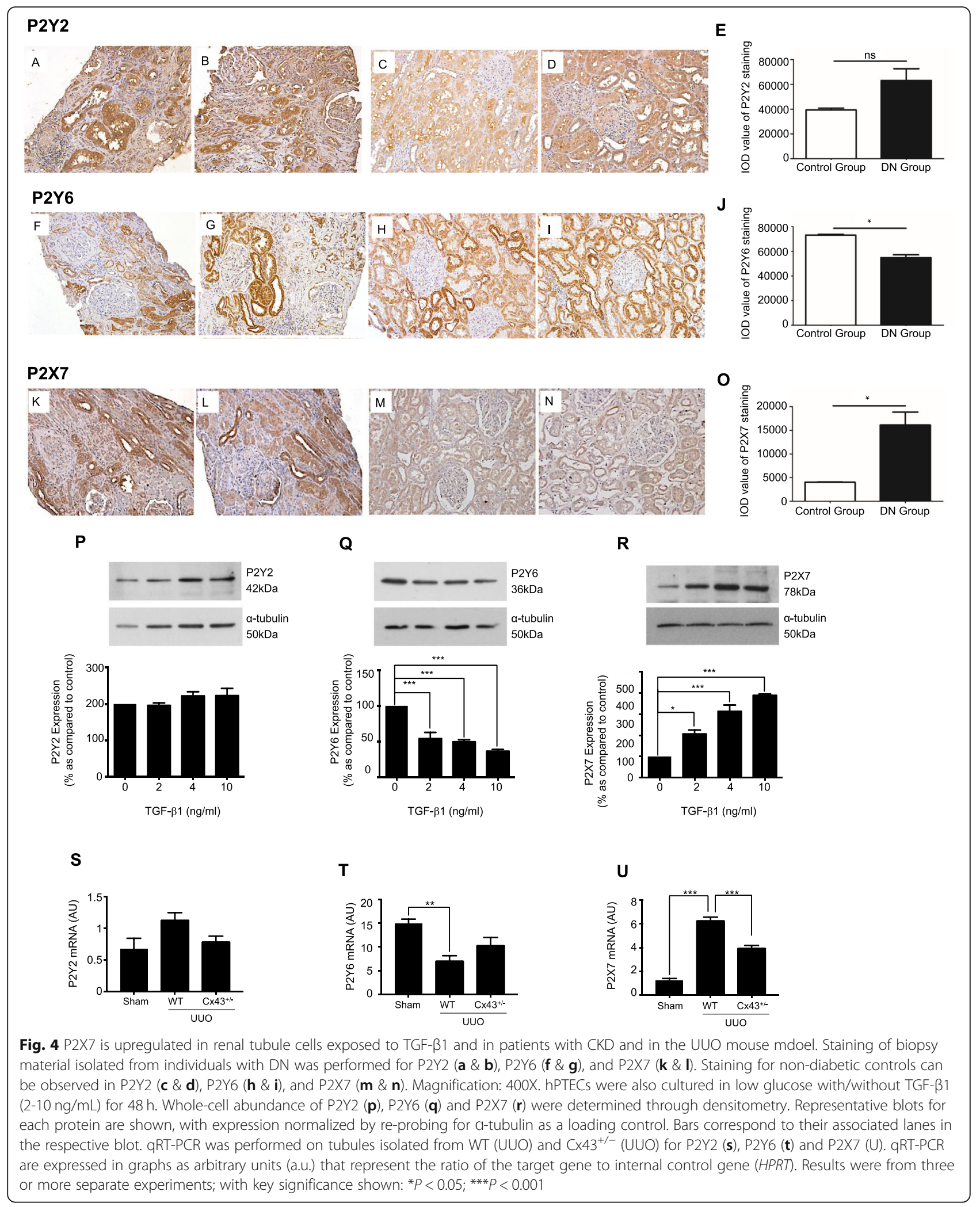



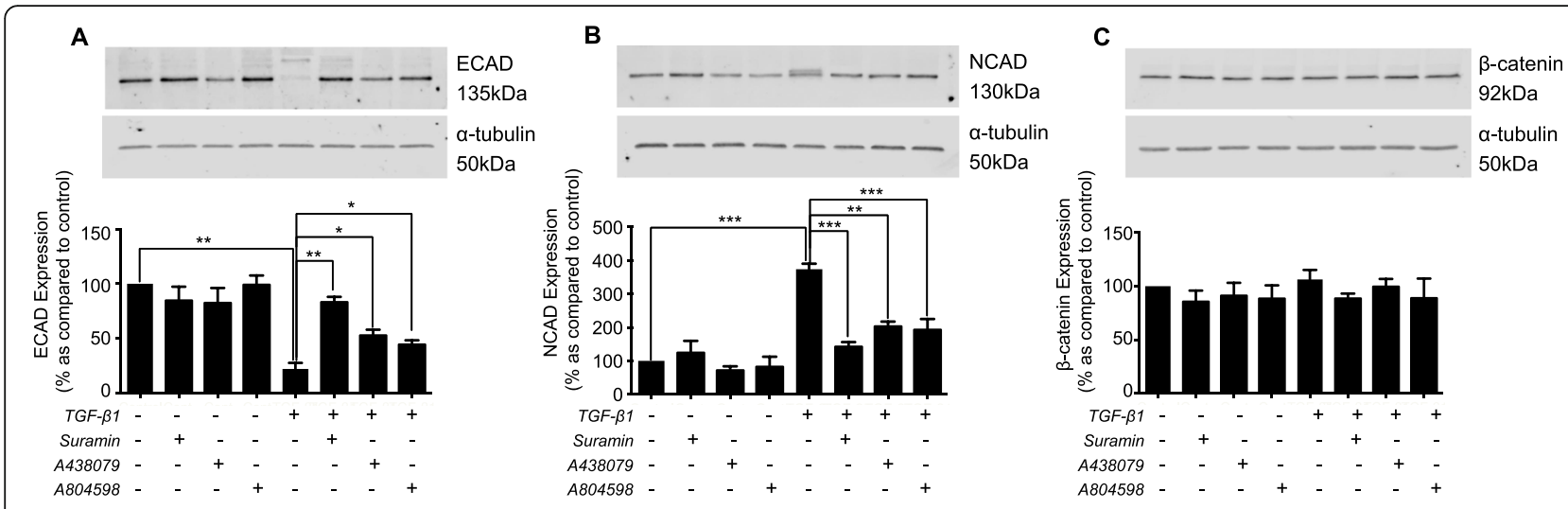

D

$E$
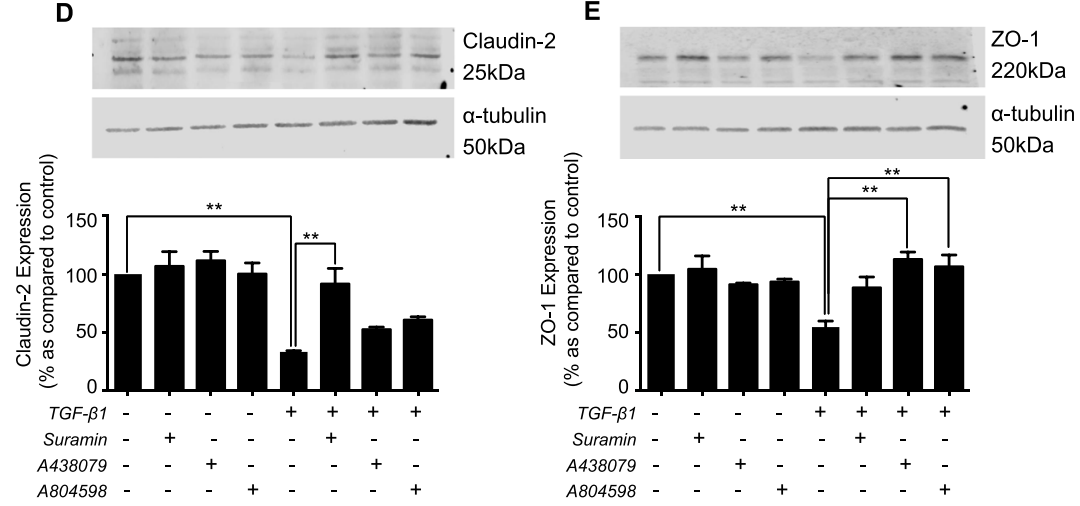

Fig. 5 Blockade of purinoreceptors attenuates TGF- $\beta 1$ induced changes in expression of adherens and tight junction protein. HK2 cells were

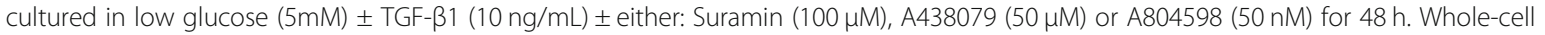
expression of E-cadherin (a), N-cadherin (b), $\beta$-catenin (c), Claudin-2 (d) and ZO-1 (e) were assessed via immunoblotting. Representative blots for each protein are shown, with expression normalized by re-probing for a-tubulin as a loading control. Bars correspond to their associated lanes in the respective blot. Results were from three or more separate experiments; with key significance shown: ${ }^{*} P<0.05$; ${ }^{* *} P<0.01$; ${ }^{* * *} P<0.001$

\section{$22.2 \pm 5.5 \% \quad$ to $\quad 83.1 \pm 5 \% \quad$ (Suramin), $\quad 52.8 \pm 5.4 \%$} (A438079) and $44.4 \pm 4 \%$ (A804598), whilst NCAD expression (Fig. 5b) decreased from $374 \pm 16.3 \%$ to $141.8 \pm$ $14.4 \%$ (Suramin), $202.5 \pm 15 \%$ (A438079) and $192.5 \pm$ $32.6 \%$ (A804598). No change in $\beta$-catenin was observed (Fig. 5c).

Inhibition of P2X7 partially reversed loss of tight junction protein expression evoked by TGF- $\beta 1$. Claudin-2 (Fig. $5 \mathrm{~d}$ ) levels were restored from $33.4 \pm 1 \%$ to $91.5 \pm 13.4 \%$ (Sura$\mathrm{min}), 52.6 \pm 2.1 \%$ (A438079) and $60.7 \pm 2.8 \%$ (A804598) and ZO-1 (Fig. 5e) returned from $54.5 \pm 5.2 \%$ to $88.3 \pm$ 9.3\% (Suramin), $112.8 \pm 6.3 \%$ (A438079) and 106.4 $\pm 10.1 \%$ (A804598). For all experiments, inhibitors alone failed to induce any significant change in expression.

\section{Peptide 5 inhibits TGF- $\beta 1$-induced Cx43 hemichannel activity and ATP release}

To study the efficacy of Peptide 5 in blocking Cx43 mediated hemichannel activity in renal tubule epithelial cells, HK2 and hPTECs were incubated in TGF- $\beta 1$ (10 $\mathrm{ng} / \mathrm{mL}) \pm$ Peptide $5(25 \mu \mathrm{M})$ for $48 \mathrm{~h}$. Dye uptake increased in TGF- $\beta 1$-treated HK2 cells to $609.4 \pm 46 \%$ compared to unstimulated control (Fig. 6a \& b), whilst co-incubation with Peptide 5 reduced uptake to $163 \pm$ $10.2 \%$. Co-incubation with scrambled peptide failed to blunt the TGF- $\beta 1$ response $(671.5 \pm 29.5 \%$, Fig. $6 a$ \& b). The effects were matched in primary hPTECS, where Peptide 5 significantly reduced uptake to $141.7 \pm 16.3 \%$ from $311.2 \pm 39.6 \%$ in TGF- $\beta 1$ treated cells (Fig. 6c \& d). Scrambled control failed to reverse the TGF- $\beta 1$ effects $(323.3 \pm 58.1 \%)$.

Biosensing uses enzymatically-coated electrodes to measure real time ATP release. Cultured as above, ATP release increased from $0.43 \pm 0.03 \mu \mathrm{M}$ to $6.10 \pm 0.36 \mu \mathrm{M}$ in TGF- $\beta 1$-treated cells (Fig. 6e \& f). Peptide 5 successfully prevented ATP release, restoring levels to $0.60 \pm$ $0.20 \mu \mathrm{M}$. Scrambled peptide in the presence of TGF- $\beta 1$ had no affect $(5.45 \pm 0.53 \mu \mathrm{M}$, Fig. $6 \mathrm{e} \& \mathrm{f})$.

\section{Peptide 5 negates TGF- $\beta 1$ induced disassembly of the} adherens and tight junction complex in human primary renal tubule cells

Having confirmed the efficacy of Peptide 5, a role for TGF- $\beta 1$ induced Cx43 mediated hemichannel ATP 


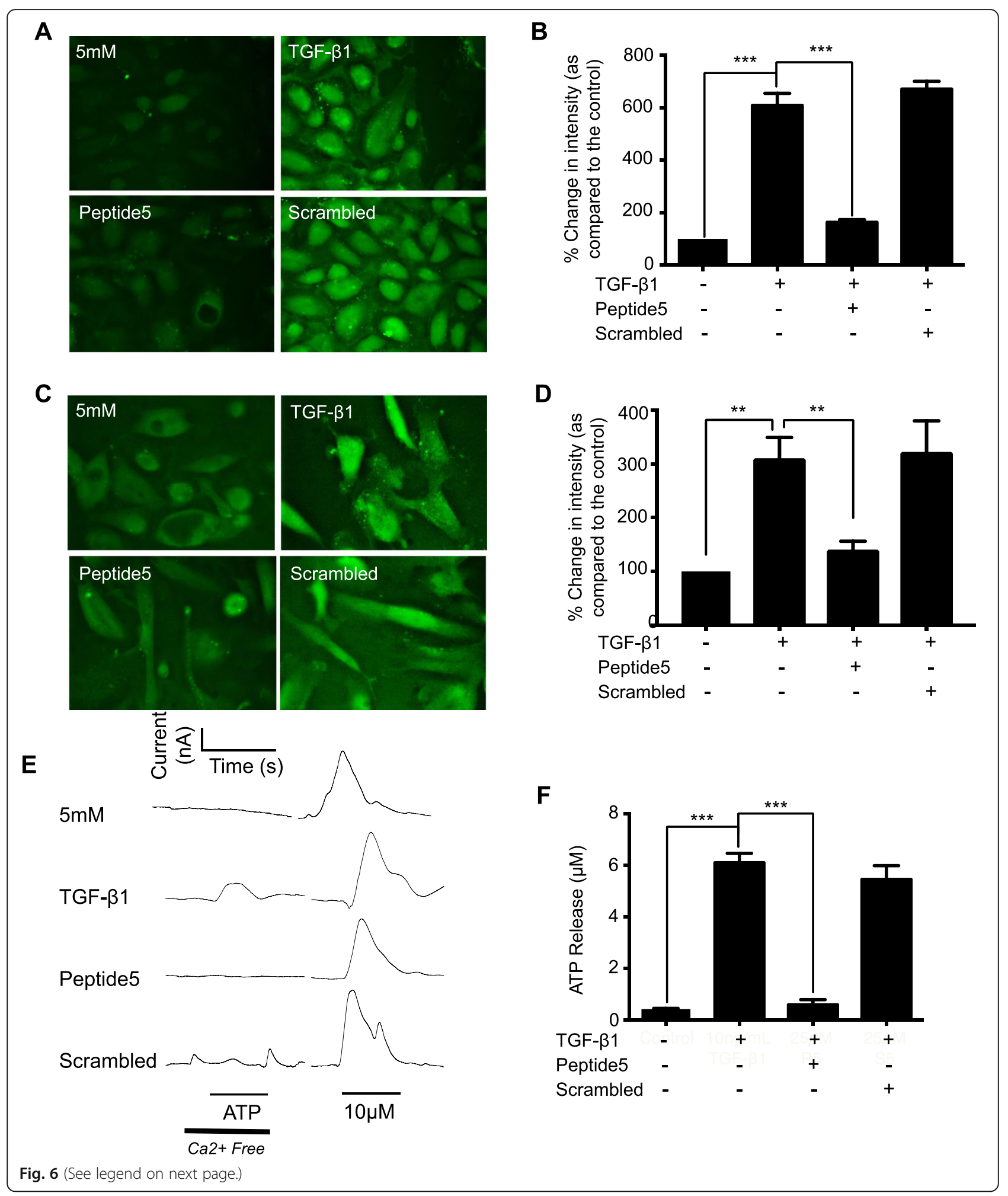


(See figure on previous page.)

Fig. 6 Co-incubation of TGF- $\beta 1$ treated renal tubule cells with Cx43 mimetic, Peptide 5, impairs hemichannel activity and ATP release. HK2 cells and hPTECs were cultured on either fluorodishes or glass coverslips in low-glucose $(5 \mathrm{mM}) \pm$ TGF- $\beta 1(10 \mathrm{ng} / \mathrm{mL}) \pm$ Peptide 5 (25 $\mu \mathrm{M})$ for $48 \mathrm{~h}$. A carboxyfluorescein uptake assay $(\mathbf{a} \& \mathbf{c})$ assessed hemi-channel activity in HK2 and hPTEC cells respectively. Minimal dye uptake was observed in control cells, whilst strong dye loading occurred in TGF- $\beta 1$ treated cells. Co-incubation with Peptide 5 attenuated dye loading, whilst a scrambled control had no significant effect. Pixel intensity of dye loading was quantified and compared to the low-glucose control (b \& d) for 10 cells in 3 separate experiments. Biosensors were used to measure hemi-channel dependent release of ATP. Representative traces (-null) are shown (e). The amplitude of any major ATP peak was measured and compared to control recordings, where little response occurred in response to hemichannel opening following the removal of calcium. TGF- $\beta 1$-treated cells exhibit significant ATP in response to hemi-channel opening, an effect negated when co-incubated with Peptide $5(25 \mu \mathrm{M})(\mathbf{f})$. Exogenous ATP was administered at the end of each experiment ensuring effective calibration. Data is expressed as mean \pm SEM of multiple cells from 4 separate experiments, with key significances shown: ${ }^{* *} P<0.01$, ${ }^{* * *} P<0.001$

release in initiating early changes of tubular injury were assessed. Human renal proximal tubule epithelial cells were incubated with TGF- $\beta 1(10 \mathrm{ng} / \mathrm{mL}) \pm$ Peptide 5 $(25 \mu \mathrm{M})$ for $48 \mathrm{~h}$. Co-incubation of hPTECs with TGF$\beta 1$ and Peptide 5 restored ECAD expression (Fig. 7a) from $31.5 \pm 9.2 \%$ to $108.9 \pm 17.1 \%$; NCAD expression (Fig. 7b) from $280.5 \pm 16.7 \%$ to $154.7 \pm 10.6 \%$; Claudin- 2 expression (Fig. 7c) $65.3 \pm 5.4 \%$ to $100.9 \pm 10 \%$ and finally ZO-1 expression (Fig. 7c) from $59.63 \pm 3.1 \%$ to $91.6 \pm 12.8 \%$ as compared to low-glucose control. Incubation of cells with either Peptide 5 alone or a scrambled version of Peptide 5, failed to change expression of our candidate proteins.

\section{Regulation of junctional components in UUO mice is Cx43-dependent}

Having confirmed a role for $\mathrm{Cx} 43$ mediated ATP release in TGF- $\beta 1$ induced tubular injury pharmacologically, the expression of key candidate proteins was assessed in vivo using our $\mathrm{C} \times 43^{+/-}$mouse model of UUO. Quantification of immunohistochemistry determined an increase in N-cadherin from $0.131 \pm 0.02 \%$ to $1.59 \pm 0.19 \%$ (Fig. 8a \& c) and a decrease in ZO-1 from $2.38 \pm 0.43 \%$ to $0.293 \pm 0.02 \%$ (Fig. $8 \mathrm{~b} \& \mathrm{~d}$ ) in UUO mice compared to WT healthy animals. Genetic depletion of $\mathrm{Cx} 43$ partially negated these changes, returning expression to $0.734 \pm 0.13 \%$ (Fig. 8a) and $0.402 \pm 0.04 \%$ (Fig. 8b) for $\mathrm{N}$ cadherin and ZO-1 respectively. Staining in $\mathrm{Cx} 43^{+/-}$ sham animals was unaltered from WT sham controls for both proteins.

In accordance with previous data, expression of Ecadherin was downregulated from $115.79 \pm 14.34 \%$ to $66.61 \pm 4.91 \%$ (Fig. 8e \& f); $\beta$-catenin upregulated from $126.04 \pm 18.38 \%$ to $880.42 \pm 16.76 \%$ (Fig. $8 \mathrm{e} \&$ g) and Claudin-2 downregulated from $107.15 \pm 3.68 \%$ to $100.61 \pm 8.63 \%$ (Fig. $8 \mathrm{e} \& \mathrm{~h}$ ), in WT UUO mice as compared to WT shams. In Cx43 ${ }^{+/-}$UUO mice, expression of E-cadherin was restored to $98.73 \pm 10.25 \%$ (Fig. 8e \& f) and $\beta$-catenin to $376.43 \pm 18.56 \%$ (Fig. $8 \mathrm{e} \& \mathrm{~g}$ ). Claudin-2 exhibited minimal change at $109.08 \pm 20.23 \%$ (Fig. 8e \& h).

\section{Discussion}

Tubulointerstitial fibrosis is the final common pathway in CKD, yet treatment represents an unmet clinical need. The emerging field of connexins suggests that these membrane bound proteins may offer a viable therapeutic target in future treatment of disease [46], with recent studies confirming that increased expression of $\mathrm{Cx} 43$ in the proximal region of the diabetic kidney, is accompanied by loss of gap junction mediated intercellular communication and increased hemichannel mediated ATP release [11]. Elevated levels of ATP have been linked to inflammation and fibrosis in multiple disease states [2831]. And work within our laboratory confirms increased expression of inflammatory and profibrotic markers in ATP treated human primary proximal tubule cells [11]. In the current study we investigate a role for aberrant Cx43 mediated hemichannel activity in mediating the phenotypic and functional changes of early tubular injury [11].

As the key underlying pathology of End Stage Renal Disease, tubulointerstitial fibrosis is partly contributed to, by Epithelial to Mesenchymal Transition (EMT) [32]. EMT occurs in the face of injury as cells attempt to evade apoptosis. In doing so, cells downregulate markers commonly associated with an epithelial phenotype, e.g. E-cadherin, ZO-1, and Claudin-2 whilst upregulating those more commonly associated with a mesenchymal phenotype and increased fibrosis, e.g. $\alpha$-SMA, Ncadherin, and Snail [32-34]. Initiation is associated with disassembly and breakdown of adherens junctions and tight junctions, culminating in loss of cell adhesion and increased paracellular permeability.

Previous findings from our lab, confirm that TGF- $\beta 1$ mediates morphological and phenotypic changes characteristic of EMT in both HK2 and hPTECs [11, 27]. Furthermore, TGF- $\beta 1$ evokes an increase in $\mathrm{Cx} 43$ expression, an effect dependent upon SMAD2/SMAD3 signalling [11], and corroborated by multiple studies confirming direct binding of Smad3 and Smad4, to the promoter of Gja1 [47, 48]. As previously reported in podocytes, it is plausible that TGF- $\beta 1$ may, via crosstalk with the STAT1 signalling pathway [21] mediate Cx43 
A
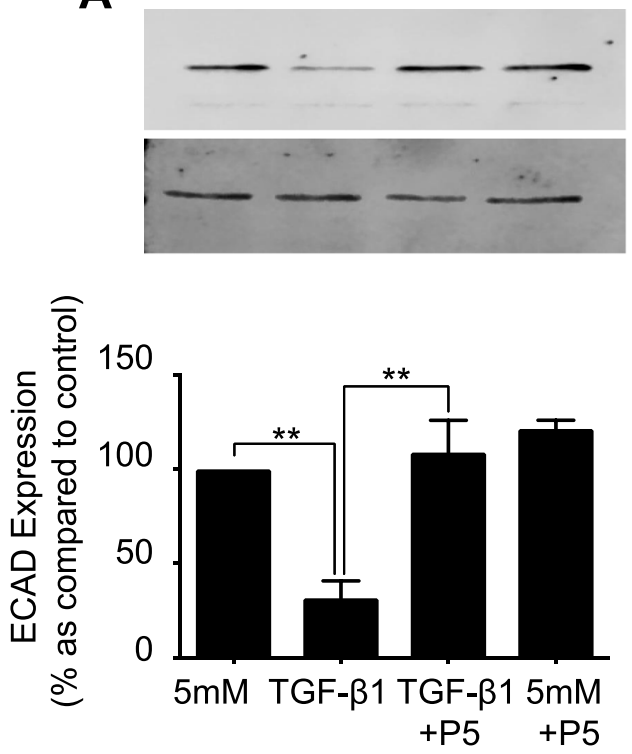

C

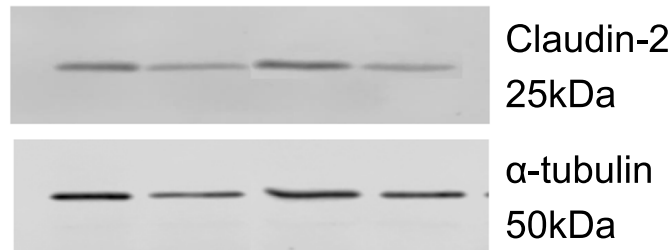

B

ECAD
$135 \mathrm{kDa}$
a-tubulin
$50 \mathrm{kDa}$

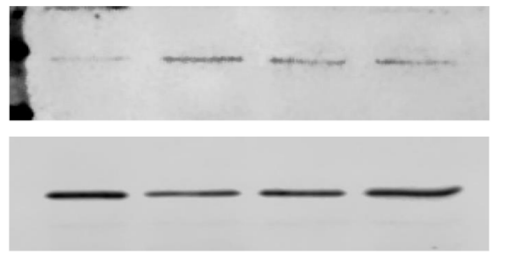

NCAD $130 \mathrm{kDa}$ a-tubulin $50 \mathrm{kDa}$

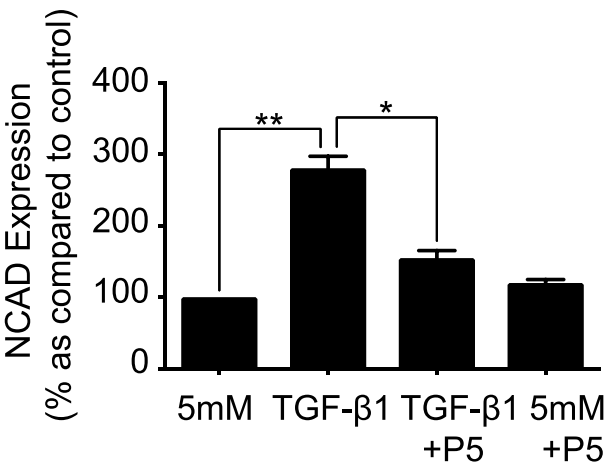

D
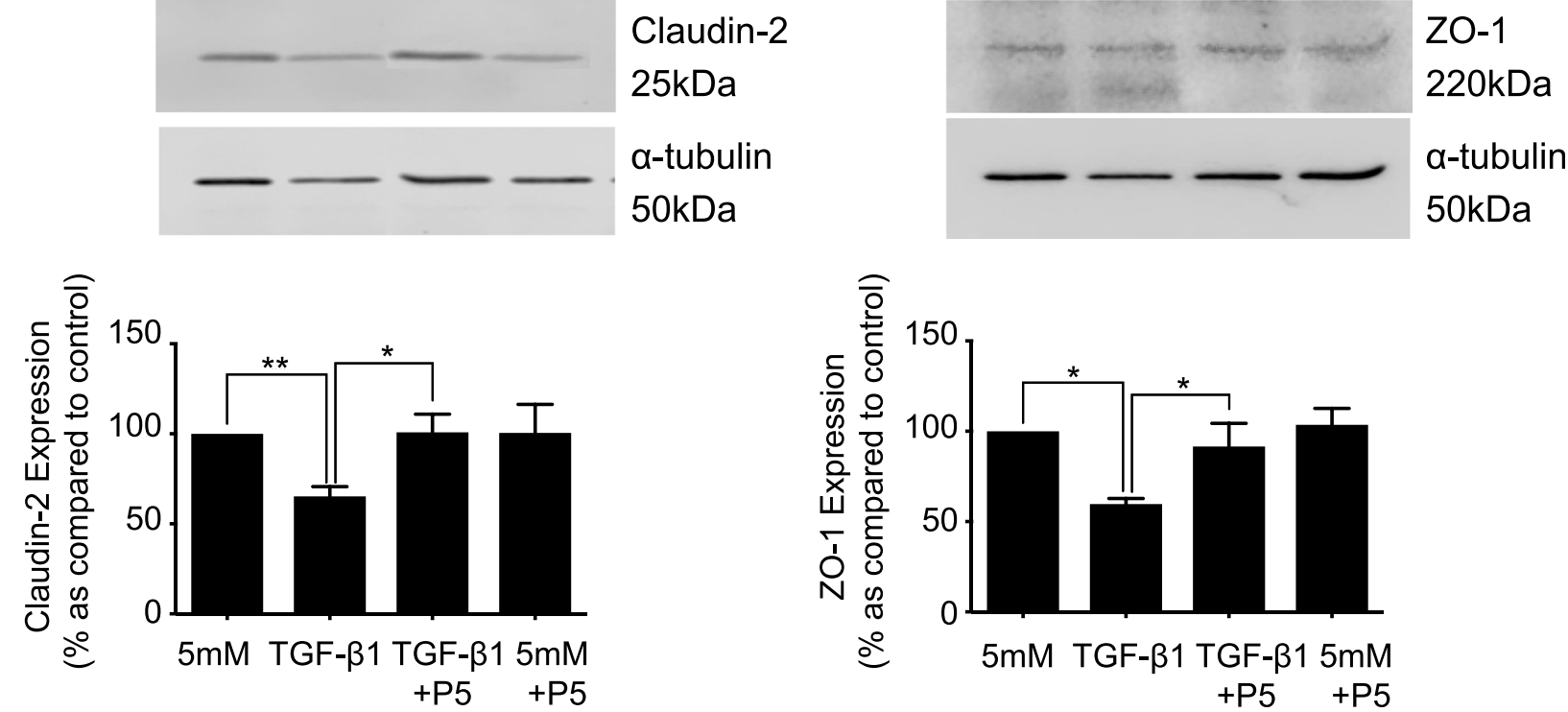

Fig. 7 Blockade of Cx43-mediated hemichannel ATP release, negates the TGF- $\beta 1$-induced disassembly of the tight and adherens junction complex. hPTECs were cultured in low glucose $(5 \mathrm{mM}) \pm$ TGF- $\beta 1(10 \mathrm{ng} / \mathrm{mL}) \pm$ Peptide $5(25 \mu \mathrm{M})$ for $48 \mathrm{~h}$. Expression of E-cadherin (a), N-cadherin (b), Claudin-2 (c) and ZO-1 (d) were assessed via western blotting. Representative blots for each protein are shown, with expression normalized by re-probing for a-tubulin as a loading control. Bars correspond to their associated lanes in the respective blot. Results were from three or more separate experiments; with significance shown: ${ }^{*} P<0.05 ;{ }^{*} P<0.01$

hemichannel expression via AKT/p38 signaling and the binding of STAT1/c-Jun to the Cx43 promoter [21]. In the current study; we present novel evidence that TGF$\beta 1$ evokes increased Cx43 hemichannel-mediated ATP release, which in turn, contributes to purinergic mediated disassembly of tight junctions and adherens junctions in the proximal region of the diseased kidney.
Our In vitro studies confirm that incubation of renal proximal tubule cells with TGF- $\beta 1$, or non-hydrolysable ATP $\gamma \mathrm{S}$ decreased expression of E-cadherin, Claudin-2 and $\mathrm{ZO}-1$, with increased expression of $\mathrm{N}$-cadherin. To delineate the functional consequences of these altered levels of expression, atomic force microscopy force spectroscopy and trans-epithelial electrical resistance 


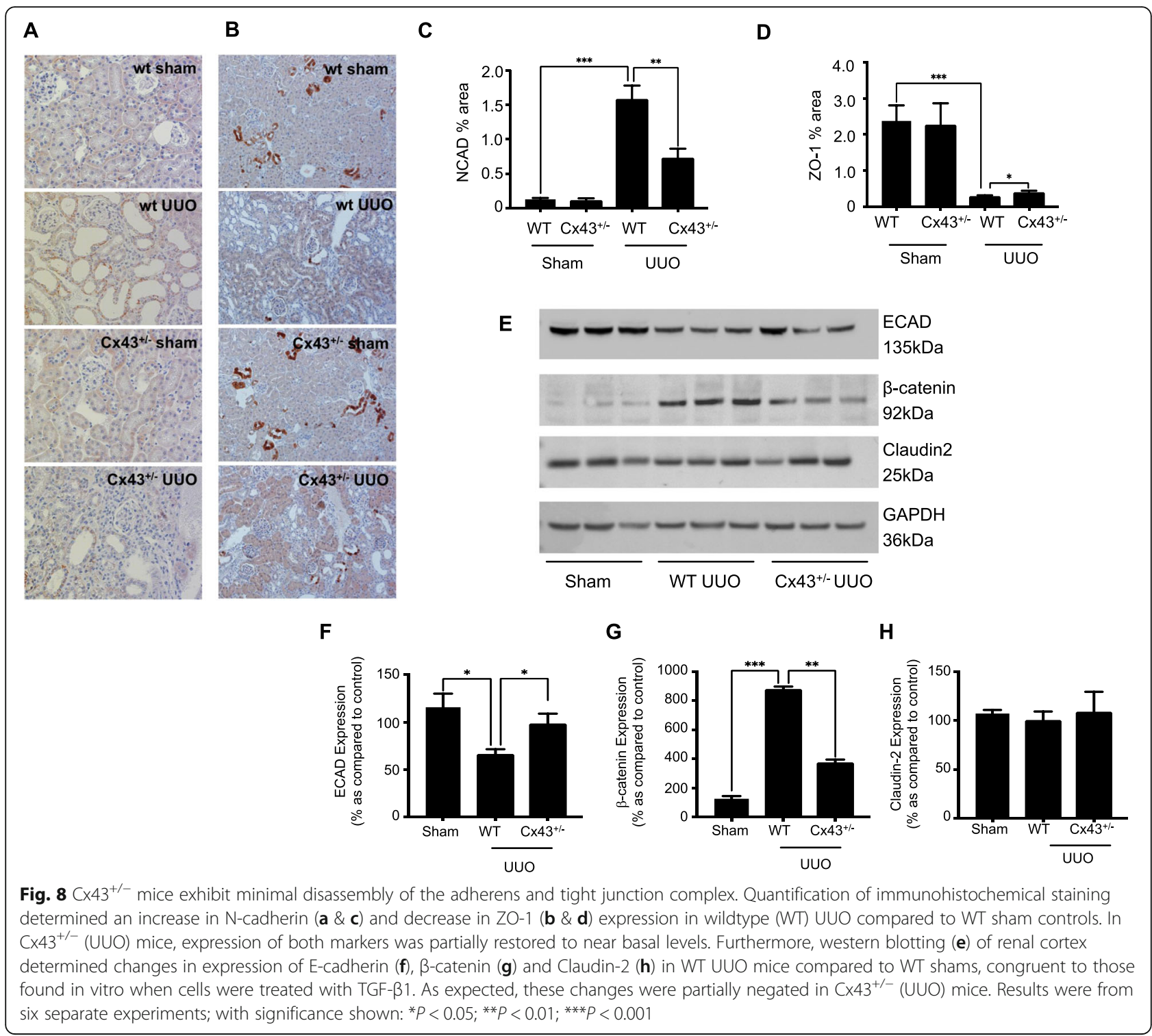

assessed changes in cell-cell tethering and paracellular permeability respectively. Corroborating recent findings that depletion of Claudin-2 and ZO-1 is detrimental to proximal tubule epithelial cell function through a "leaky" epithelia, [49] both TGF- $\beta 1$ and ATP $\gamma$ S independently reduce PTEC resistance, and ultimately impair barrier integrity. Furthermore, force spectroscopy confirmed $\mathrm{ATP} Y \mathrm{~S}$ reduced the unbinding force required to uncouple two attached cells. Co-incubation of TGF- $\beta 1$ with the ectonucleotidase apyrase, partially restored expression of E-cadherin and $\mathrm{N}$-cadherin, yet failed to negate TGF- $\beta 1$ evoked changes in tight junction protein expression. These observations, can most likely be explained by studies confirming a role for ATP metabolites in regulating expression of tight junction proteins, $[50,51]$ and are further supported by observations that TGF- $\beta 1$ evoked changes in tight junction expression are blunted when cells are co-incubated with adenosine receptor antagonist; Suramin. The origin of this deleterious signal was confirmed in TGF- $\beta 1$ treated cells preincubated with Peptide 5. Peptide 5 is a 12 amino acid peptide which targets the 2nd extracellular loop of Cx43 [52], it has been proven successful in blocking Cx43 hemichannels when delivered topically, intraocularly [53], into cerbebrospinal fluid and systemically [52]. Multiple approaches have been used to confirm target applicability and specificity and all have yielded similar and significant benefits across different injury models. The ability of Peptide 5 to block hemichannel activity, ATP-release and ultimately disassembly of the adherens/tight junction complex in our model system, was assessed by carboxyfluorescein dye uptake, ATP-biosensing and 
western blotting respectively. Co-incubation of both HK2 and hPTECS with TGF- $\beta 1$ and Peptide 5 significantly reduced dye uptake and restored ATP release to near basal, whilst Peptide 5 successfully prevented TGF$\beta 1$-evoked changes in expression of E-cadherin, $\mathrm{N}$ cadherin, Claudin-2 and ZO-1 in human primary renal proximal tubule cells.

Confirmation for $\mathrm{Cx} 43$ mediated ATP release in initiating these changes of early tubular injury, was confirmed in a $\mathrm{Cx}_{4} 3^{+/-}$heterogeneous knockout mouse model having undergone unilateral ureteral obstruction (UUO). The UUO model recapitulates the fundamental pathogenic mechanisms that typify all forms of CKD including diabetic nephropathy and is widely used for the study of renal fibrosis and inflammation [36]. Staining renal cortex slices from wildtype UUO mice confirmed a decrease in $\mathrm{N}$-cadherin and ZO-1 expression, whilst immunoblotting of isolated renal cortex protein demonstrated reduced E-cadherin expression, with increased expression of $\beta$-catenin. Restoration of expression of the adherens junction proteins in the $\mathrm{C} \times 43^{+/-}$UUO model supports our earlier findings where $\mathrm{Cx} 43$ block diminished hemichannel mediated ATP release. However, whilst changes in expression of our adherens junction proteins were recapitulated in vivo, minimal change was observed for tight junction protein Claudin-2. Despite this, ZO-1 expression was decreased in vitro and in vivo, an effect restored when hPTEC cells were co-incubated with Peptide 5, or Cx43 activity was suppressed $\left(\mathrm{Cx} 43^{+-}\right)$. The importance of this to tubular function and subsequent injury, is supported by observations, which suggest that ZO-1 is a critical regulator of tight junction assembly $[54,55]$, with loss of expression linked to defects in tight junction assembly and a severely disrupted paracellular barrier [54-56]. Although not present in the mature adherens junction complex, tight junction biogenesis is characterized by an interaction between ZO-1 and cadherins, an association which allows for fusion of belt-like tight junctions and gap junction formation [57]. In addition, in its capacity as a scaffolding protein, $\mathrm{ZO}-1$ directly facilitates $\mathrm{Cx} 43$ mediated gap junction formation [58]. Thus, restoration of ZO-1 expression, through blockade of $\mathrm{Cx} 43$ hemichannel mediated ATP release, has potential to not just restore barrier function, but to maintain cell-to-cell adhesion through efficient adherens junction formation, blockade of EMT and restoration of direct GJIC.

With an imbalance in ATP signalling \&/or degradation linked to the underlying pathology of multiple diseases [59-61], we investigated a role for downstream purinergic signalling in driving these $\mathrm{Cx} 43$ hemichannel mediated events. ATP signals via activation of membrane-bound purinoreceptors [62]. Increased activation of purinergic receptors, notably $\mathrm{P} 2 \mathrm{X} 7$, has been linked to inflammatory damage in the renal vasculature, glomerulus and tubular regions in multiple experimental models of kidney disease [62-64]. In diabetic nephropathy, P2X7 expression is associated with mesangial expansion and impaired glomerular filtration [38], whilst genetic and pharmacological (AZ11657312) ablation of P2X7 in a mouse model of Type I diabetes impaired glomerular macrophage infiltration and decreased collagen IV deposition [38]. In human biopsy material from people with diabetic nephropathy and in tubules isolated from the UUO mouse model, we observed a significant upregulation of $\mathrm{P} 2 \mathrm{X} 7$ expression, an effect which was blunted when $\mathrm{Cx} 43$ expression was genetically reduced $\left(\mathrm{C} \times 43^{+/-} / \mathrm{UUO}\right)$. Peptide 5 , has been shown to negate inflammation and associated tissue damage in multiple systems of disease, specifically those where initial pathology appears perpetuated by activation of the nucleotide-binding domain and leucine-rich repeat containing (NLR) protein-3 (NLRP3) inflammasome [65]. Upregulated in classic immune cells (e.g. infiltrating macrophages) and tubular epithelial cells of the kidney, the NLRP3 inflammasome is a protein complex involved in initiating the innate immune response [66], with activation linked to a variety of glomerular and tubulointerstitial diseases $[67,68]$. Although pharmacological inhibition negates inflammation and improves overall tissue function in a host of inflammatory conditions, lack of understanding of structure and underlying regulatory mechanisms of NLRP3 has hindered the discovery and development of successful therapeutics [66].

Stimulated by age-related Damage-associated molecular patterns (DAMPs), including excess ATP, P2X7 mediated activation of the NLRP3 complex triggers a cascade of events that culminate in secretion of downstream pro-inflammatory mediators, including interleukin-1 $\beta$ (IL-1 $\beta$ ) and interleukin-18 (IL-18) [66]. A recent study in acute renal injury confirmed that the $\mathrm{C} \times 43^{+/-}$mouse exhibits reduced renal NLRP3 expression and decreased serum levels of IL-1 $\beta$ as compared to its wildtype control [69]. Moreover, NLRP3 activation has recently been linked to induction of EMTand diminished ECAD expression in multiple cell types [70, 71], whilst Cx43 mediated NLRP3 activation initiates breakdown and disruption of the retinal pigment epithelium (RPE) at the back of the diabetic eye [65]. In addition, with priming of the NLRP3 inflammasome linked to nuclear factor-kappa B (NF- $\mathrm{kB})$ activation, combined with reports that NF- $\mathrm{KB}$ activation binding to the $\mathrm{Cx} 43$ gene promoter directly increases $\mathrm{Cx} 43$ expression [72], it is possible that inflammasome pathway priming parallels increased Cx43 expression, further perpetuating aberrant Cx43 mediated ATP release [65]. The current study confirms that specific inhibition of P2X7 in PTECS coincubated with TGF- $\beta 1+/-$ P2X7 inhibitor A438079 or 
A804598, negates TGF- $\beta 1$-evoked changes in expression of EMT markers, E-cadherin, N-cadherin, Claudin-2 and ZO-1. In addition, using AFM-SCFS, we have recently shown that the ATP $\gamma \mathrm{S}$ induced downregulation of Ecadherin expression in proximal kidney cells, is paralleled by a P2X7 mediated reduction in intercellular ligation forces, decreased tether rupture events and cytoskeletal remodeling [73]. Combined with observations that Peptide 5 negates TGF- $\beta 1$ induced disassembly of the adherens junction and tight junction complex, our findings suggest that TGF- $\beta 1$ evoked changes in $\mathrm{Cx} 43$ mediated ATP likely initiates P2X7 mediated tubular injury and EMT via an NLRP3 dependent mechanism.

However, although blockade of P2X7 and an impaired ATP driven response clearly supports a role for purinergic mediated signalling in early tubular injury, recent clinical trials have failed to demonstrate a beneficial effect of P2X7 antagonism in numerous inflammatory illnesses, an effect most likely linked to the genetic variation within the P2X7 [74]. With aberrant Cx43 activity linked to activation of $\mathrm{P} 2 \mathrm{X} 7$ and NLRP3, targeting aberrant Cx43 mediated hemichannel ATP release clearly represents a future therapeutic avenue for the treatment of chronic kidney disease and other conditions where inflammation appears to be the underlying pathology.

\section{Conclusions}

Our study is the first to provide insight into the initiating trigger of early phenotypic changes, which predispose cells of the injured proximal tubule to tubular injury. Elevated levels of TGF- $\beta 1$ increase Cx43 hemichannel mediated ATP release, an effect which drives P2X7 mediated phenotypic changes linked to initiation of EMT in the tubular region of the kidney. With previous work in the $\mathrm{Cx} 43^{+/-}$UUO model linking reduced Cx43 expression to diminished levels of extracellular matrix deposition, fibroblast activation and macrophage infiltration [24], the current study utilises Peptide 5 and confirms that the protective effects as observed in the $\mathrm{C} \times 43^{+/-}$UUO mouse, appear to stem from inhibition of aberrant Cx43 mediated hemichannel ATP release. In conclusion, $\mathrm{Cx} 43$ represents, a viable therapeutic intervention for tubular damage in late stage CKD via restoration of the phenotypic and functional changes that culminate in an inflammatory and fibrotic phenotype.

\section{Abbreviations}

ATP: Adenosine triphosphate; AJ: Adherens junction; CKD: Chronic Kidney Disease; Cx43: Connexin43; HK2: Clonal tubular epithelial cells; ECAD: Ecadherin; GJC: Gap junction mediated intercellular communication; hPTECS: Human primary proximal tubule epithelial cells; NCAD: N-cadherin; TGF-B1: Transforming Growth Factor; TJ: Tight Junction; TIF: Tubulointerstitial Fibrosis; UUO: Unilateral ureteral obstruction; Z0-1: Zona-Occludin

\section{Acknowledgements}

Not Applicable.

\section{Authors' contributions}

CEH, and PES designed the study. GWP, JAP, ES, CC, PK, and WHY carried out the experiments. GWP, CC, JAP, SCT and WHY analysed the data. CEH and GWP made the figures. All authors were involved in the drafting and revision of the paper and approved the final manuscript. All authors read and approved the final manuscript.

\section{Authors' information}

Not Applicable.

\section{Funding}

CEH \& PES would like to acknowledge the generous support of Diabetes UK (11/0004215, 16/0005427 16/0005509 16/005544), Diabetes Research and Wellness Foundation, and an EFSD/ Boehringer Kidney Award in funding this work.

\section{Availability of data and materials}

The datasets used and/or analysed during the current study are available from the corresponding author on reasonable request.

\section{Ethics approval and consent to participate}

All human tissue staining was approved by the institutional review board at the University of Hong Kong / Hospital Authority Hong Kong West Cluster. All animal work was approved by the appropriate committee of the National Institute for Health and Medical Research (INSERM) and the Sorbonne Université (Paris, France).

\section{Consent for publication \\ Not Applicable.}

\section{Competing interests}

The authors declare that they have no competing interests.

\section{Author details}

'Joseph Banks Laboratories, School of Life Sciences, University of Lincoln, Green Lane, Lincoln, UK. National Institutes for Health and Medical Research Unite Mixte de Recherche S1155, Batiment Recherche, Tenon Hospital, 4 rue de la Chine, 75020 Paris, France. ${ }^{3}$ Division of Nephrology, Department of Medicine, The University of Hong Kong, Hong Kong, Hong Kong. ${ }^{4}$ Department of Ophthalmology, New Zealand National Eye Centre, University of Auckland, Auckland, New Zealand.

Received: 12 September 2019 Accepted: 23 March 2020

Published online: 25 May 2020

\section{References}

1. Neuen BL, Chadban SJ, Demaio AR, Johnson DW, Perkovic V. Chronic kidney disease and the global NCDs agenda. BMJ Glob Health. 2017;2(2):e000380.

2. Rossing P, Frimodt-Møller M. Diabetic nephropathy. Pathophysiol Clin Aspects - Clinical Features and Natural Course of Diabetic Nephropathy. 2018:21-32.

3. Liu BC, Tang TT, Lv LL, Lan HY. Renal tubule injury: a driving force toward chronic kidney disease. Kidney Int. 2018;93(3):568-79.

4. Schnaper HW. The Tubulointerstitial pathophysiology of progressive kidney disease. Adv Chronic Kidney Dis. 2017;24(2):107-16.

5. Delmar M, Laird DW, Naus CC, Nielsen MS, Verselis VK, White TW. Connexins and disease. Cold Spring Harb Perspect Biol. 2018;10:a029348.

6. Hernández-Guerra M, Hadjihambi A, Jalan R. Gap junctions in liver disease: implications for pathogenesis and therapy. J Hepatol. 2019;70(4):759-72.

7. Giaume C, Sáez JC, Song W, Leybaert L, Naus CC. Connexins and pannexins in Alzheimer's disease. Neurosci Lett. 2019;16(695):100-5.

8. Zhou KQ, Green CR, Bennet L, Gunn AJ, Davidson JO. The role of Connexin and Pannexin channels in perinatal brain injury and inflammation. Front Physiol. 2019;27(10):141.

9. Prakoura N, Kavvadas P, Chadjichristos CE Connexin 43: a new therapeutic target against chronic kidney disease. Cell Physiol Biochem. 2018;49(3):985.

10. Bosco D, Haefliger JA, Meda P. Connexins: key mediators of endocrine function. Physiol Rev. 2011;91(4):1393-445. 
11. Hills C, Price GW, Wall MJ, Kaufmann TJ, Chi-Wai Tang S, Yiu WH, et al. Transforming growth factor Beta 1 drives a switch in Connexin mediated cell-to-cell communication in tubular cells of the diabetic kidney. Cell Physiol Biochem. 2018;45(6):2369-88.

12. Hills CE, Price GW, Squires PE. Mind the gap: connexins and cell-cell communication in the diabetic kidney. Diabetologia. 2015;58(2):233-41.

13. Roy $S$, Kim D, Lim R. Cell-cell communication in diabetic retinopathy. Vis Res. 2017;139:115-22.

14. Li H, Wang F. The role of connexin43 in diabetic microvascular complications. Discov Med. 2016;22(122):275-80.

15. Becker DL, Thrasivoulou C, Phillips AR. Connexins in wound healing; perspectives in diabetic patients. Biochim Biophys Acta. 2012;1818(8):206875.

16. Shen Z, Chen $Q$, Jin T, Wang M, Ying H, Lu J, et al. Theaflavin 3,3'-digallate reverses the downregulation of connexin 43 and autophagy induced by high glucose via AMPK activation in cardiomyocytes. J Cell Physiol. 2019; 234:1-18.

17. Sáez JC, Contreras-Duarte S, Gómez GI, Labra VC, Santibañez CA, GajardoGómez R, et al. Connexin 43 Hemichannel activity promoted by proinflammatory cytokines and high glucose alters endothelial cell function. Front Immunol. 2018:9:1899.

18. Kuo C, Green CR, Rupenthal ID, Mugisho OO. Connexin43 hemichannel block protects against retinal pigment epithelial cell barrier breakdown. Acta Diabetol. 2019. https://doi.org/10.1007/s00592-019-01352-3.

19. Hills CE, Bland R, Wheelans DC, Bennett J, Ronco PM, Squires PE. Glucoseevoked alterations in connexin43-mediated cell-to-cell communication in human collecting duct: a possible role in diabetic nephropathy. Am J Physiol Renal Physiol. 2006;291(5):F1045-51.

20. Zhao Y, Li G, Wang Y, Liu Z. Alteration of Connexin43 expression in a rat model of obesity-related glomerulopathy. Exp Mol Pathol. 2018;104(1):12-8.

21. Kavvadas P, Abed A, Poulain C, Authier F, Labéjof LP, Calmont A, et al. Decreased expression of Connexin 43 blunts the progression of experimental GN. J Am Soc Nephrol. 2017;28(10):2915-30

22. Price GW, Potter JA, Williams BM, Cliff CL, Squires PE, Hills CE. Connexinmediated cell communication in the kidney: A potential therapeutic target for future intervention of diabetic kidney disease?: Joan Mott prize lecture. Exp Physiol. 2019;105(2):219-29.

23. Gerl M, Vöckl J, Kurt B, van Veen TA, Kurtz A, Wagner C. Inducible deletion of connexin 40 in adult mice causes hypertension and disrupts pressure control of renin secretion. Kidney Int. 2015;87(3):557-63.

24. Abed A, Toubas J, Kavvadas P, Authier F, Cathelin D, Alfieri C, et al. Targeting connexin 43 protects against the progression of experimental chronic kidney disease in mice. Kidney Int. 2014;86(4):768-79.

25. Rauchman M, Griggs D. Emerging strategies to disrupt the central TGF- $\beta$ axis in kidney fibrosis. Transl Res. 2019;209:90-104.

26. Meng XM, Nikolic-Paterson DJ, Lan H. TGF- $\beta$ : the master regulator of fibrosis. Nat Rev Nephrol. 2016;12:325-38.

27. Hills CE, Siamantouras E, Smith SW, Cockwell P, Liu KK, Squires PE. TGF $\beta$ modulates cell-to-cell communication in early epithelial-to-mesenchymal transition. Diabetologia. 2012;55(3):812-24.

28. Lu D, Insel PA. Hydrolysis of extracellular ATP by ectonucleoside triphosphate diphosphohydrolase (ENTPD) establishes the set point for fibrotic activity of cardiac fibroblasts. J Biol Chem. 2013;288(26):19040-9.

29. Solini A, Usuelli V, Fiorina P. The dark side of extracellular ATP in kidney diseases. J Am Soc Nephrol. 2015;26(5):1007-16.

30. Dosch M, Zindel J, Jebbawi F, Melin N, Sanchez-Taltavull D, Stroka D, et al. Connexin-43-dependent ATP release mediates macrophage activation during sepsis. Elife. 2019:8:e42670

31. Lu D, Soleymani S, Madakshire R, Insel PA. ATP released from cardiac fibroblasts via connexin hemichannels activates profibrotic $\mathrm{P} 2 \mathrm{Y} 2$ receptors. FASEB J. 2012;26:2580-91.

32. Hills CE, Squires PE. The role of TGF- $\beta$ and epithelial-to mesenchymal transition in diabetic nephropathy. Cytokine Growth Factor Rev. 2011;22(3): $131-9,2011$.

33. Bai X, Geng J, Zhou Z, Tian J, Li X. MicroRNA-130b improves renal tubulointerstitial fibrosis via repression of Snail-induced epithelialmesenchymal transition in diabetic nephropathy. Sci Rep. 2016;3(6):20475.

34. Gao L, Liu MM, Zang HM, Ma QY, Yang Q, Jiang L, et al. Restoration of Ecadherin by PPBICA protects against cisplatin-induced acute kidney injury by attenuating inflammation and programmed cell death. Lab Investig. 2018;98(7):911-23.
35. Grande MT, Sánchez-Laorden B, López-Blau C, De Frutos CA, Boutet A, Arévalo $M$, et al. Snail1-induced partial epithelial-to-mesenchymal transition drives renal fibrosis in mice and can be targeted to reverse established disease. Nat Med. 2015:21(9):989-97.

36. Betz B, Conway BR. An update on the use of animal models in diabetic nephropathy research. Curr Diab Rep. 2016;16(2):18.

37. Burnstock $G$, Knight GE. The potential of $P 2 X 7$ receptors as a therapeutic target, including inflammation and tumour progression. Purinergic Signal. 2018;14:1-18.

38. Menzies RI, Booth JWR, Mullins JJ, Bailey MA, Tam FWK, Norman JT, et al. Hyperglycemia-induced renal P2X7 receptor activation enhances diabetesrelated injury. EBioMedicine. 2017;19:73-83.

39. Cao F, Hu LQ, Yao SR, Hu Y, Wang DG, Fan YG. P2X7 receptor: A potential therapeutic target for autoimmune diseases. Autoimmun Rev. 2017:S15689972(19):30136-3.

40. Koo TY, Lee JG, Yan JJ, Jang JY, Ju KD, Han M, et al. The P2X7 receptor antagonist, oxidized adenosine triphosphate, ameliorates renal ischemiareperfusion injury by expansion of regulatory T cells. Kidney Int. 2017;92(2): 415-31.

41. Kavvadas P, Keuylian Z, Prakoura N, Placier S, Dorison A, Chadjichristos CE, et al. Notch3 orchestrates epithelial and inflammatory responses to promote acute kidney injury. Kidney Int. 2018;94:126-38.

42. Yiu W, Wong DW, Chan LY, Leung JC, Chan K, Lan H, et al. Tissue Kallikrein mediates pro-inflammatory pathways and activation of protease-activated Receptor-4 in proximal tubular epithelial cells. PLoS One. 2014;9:e88894.

43. Hills CE, Kerr MI, Wall MJ, Squires PE. Visfatin reduces gap junction mediated cell-to-cell communication in proximal tubule-derived epithelial cells. Cell Physiol Biochem. 2013;32(5):1200-12.

44. Siamantouras E, Hills CE, Squires PE, Liu KK. Quantifying cellular mechanics and adhesion in renal tubular injury using single cell force spectroscopy. Nanomedicine. 2016;12(4):1013-21.

45. Siamantouras E, Hills CE, Liu KK, Squires PE. Examining cell-cell interactions in the kidney using AFM single-cell force spectroscopy. Methods Mol Biol. 2020;2067:189-201.

46. Laird DW, Lampe PD. Therapeutic strategies targeting connexins. Nat Rev Drug Discov. 2018;17:905-21

47. Liu W, Cui Y, Sun J, Cai L, Xie J, Zhou X. Transforming growth factor- $\beta 1$ upregulates connexin43 expression in osteocytes via canonical Smaddependent signaling pathway. Biosci Rep. 2018;38(6):BSR20181678.

48. Wang Q, Zhou C, Li X, Cai L, Zou J, Zhang D, Xie J, Lai W. TGF- $\beta 1$ promotes gap junctions formation in chondrocytes via Smad3/Smad4 signalling. Cell Prolif. 2019;52(2):e12544

49. Kim S, Kim GH. Roles of claudin-2, ZO-1 and occludin in leaky HK-2 cells. PLoS One. 2017;12:e0189221.

50. Hurtado-Alvarado G, Domínguez-Salazar E, Velázquez-Moctezuma J, GómezGonzález B. A2A adenosine receptor antagonism reverts the blood-brain barrier dysfunction induced by sleep restriction. PLoS One. 2016;11(11): e0167236.

51. Curtis VF, Cartwright IM, Lee JS, Wang RX, Kao DJ, Lanis JM, et al. Neutrophils as sources of dinucleotide polyphosphates and metabolism by epithelial ENPP1 to influence barrier function via adenosine signaling. Mol Biol Cell. 2018;29(22):2687-99.

52. O'Carroll SJ, Alkadhi M, Nicholson LF, Green CR. Connexin43 mimetic peptides reduce swelling, Astrogliosis, and neuronal cell death after spinal cord injury. Cell Commun Adhesion. 2009:15:27-42.

53. Nor NM, Guo CX, Rupenthal ID, Chen YS, Green CR, Acosta ML. Sustained connexin43 mimetic peptide release from loaded nanoparticles reduces retinal and choroidal photodamage. Invest Ophthalmol Vis Sci. 2018;59(8): 3682-93.

54. Fanning $A S$, Jameson $B J$, Jesaitis LA, Anderson JM. The tight junction protein ZO-1 establishes a link between the transmembrane protein occludin and the actin cytoskeleton. J Biol Chem. 1998:273:29745-53.

55. Van Itallie CM, Fanning AS, Bridges A, Anderson JM. ZO-1 stabilizes the tight junction solute barrier through coupling to the perijunctional cytoskeleton. Mol Biol Cell. 2009;20:3930-40.

56. Umeda K, Ikenouchi J, Katahira-Tayama S, Furuse K, Sasaki H, Nakayama M, et al. ZO-1 and ZO-2 independently determine where claudins are polymerized in tight-junction strand formation. Cell. 2006;126:741-54.

57. Ikenouchi J, Umeda K, Tsukita S, Furuse M. Requirement of ZO-1 for the formation of belt-like adherens junctions during epithelial cell polarization. Cell Biol. 2007;176:779-86. 
58. Thévenin AF, Margraf RA, Fisher CG, Kells-Andrews RM, Falk MM Phosphorylation regulates connexin43/ZO-1 binding and release, an important step in gap junction turnover. Mol Biol Cell. 2017;28(25):3595608.

59. Friedman DJ, Kunzli BM, A-Rahim YI, Sevigny J, Berberat PO, Enjyoji K, et al. CD39 deletion exacerbates experimental murine colitis and human polymorphisms increase susceptibility to inflammatory bowel disease. Proc Natl Acad Sci U S A. 2009;106:16788-93.

60. Vuerich M, Robson SC, Longhi MS. Ectonucleotidases in intestinal and hepatic inflammation. Front Immunol. 2019;10:507.

61. Becker LV, Passos DF, Leal DBR, Morsch VM, Schetinger MRC. ATP signaling and NTPDase in systemic lupus Erythematosus (SLE). Immunobiology. 2019; 224(3):419-4262019.

62. Burnstock G, Evans LC, Bailey MA. Purinergic signalling in the kidney in health and disease. Purinergic Signal. 2014:10:71-101.

63. Menzies Rl, Tam FW, Unwin RJ, Bailey MA. Purinergic signaling in kidney disease. Kidney Int. 2016;91:1-9.

64. Savio LEB, de Andrade MP, da Silva CG, Coutinho-Silva R. The P2X7 receptor in inflammatory diseases: angel or demon? Front Pharmacol. 2018;9:52.

65. Mugisho OO, Green CR, Kho DT, Zhang J, Graham ES, Acosta ML, et al. The inflammasome pathway is amplified and perpetuated in an autocrine manner through connexin43 hemichannel mediated ATP release. Biochim Biophys Acta Gen Subj. 2018;1862(3):385-93.

66. Mangan MS, Olhava EJ, Roush WR, Seidel HM, Glick GD, Latz E. Targeting the NLRP3 inflammasome in inflammatory diseases. Nat Rev Drug Discov. 2018:17(8):588-606.

67. Komada T, Muruve DA. The role of inflammasomes in kidney disease. Nat Rev Nephrol. 2019;1(15):501-20.

68. Nam SA, Kim WY, Kim JW, Park SH, Kim HL, Lee MS, et al. Autophagy attenuates tubulointerstital fibrosis through regulating transforming growth factor- $\beta$ and NLRP3 inflammasome signaling pathway. Cell Death Dis. 2019; 10(2):1-10.

69. Huang Y, Mao Z, Zhang Z, Obata F, Yang X, Zhang X, et al. Connexin43 contributes to Inflammasome activation and lipopolysaccharide-initiated acute renal injury via modulation of intracellular oxidative status. Antioxid Redox Signal. 2019;31(16):1194-212.

70. Tian R, Zhu Y, Yao J, Meng X, Wang J, Xie H, Wang R. NLRP3 participates in the regulation of EMT in bleomycin-induced pulmonary fibrosis. Exp Cell Res. 2017;357(2):328-34.

71. Song S, Qiu D, Luo F, Wei J, Wu M, Wu H, et al. Knockdown of NLRP3 alleviates high glucose or TGFB1-induced EMT in human renal tubular cells. J Mol Endocrinol. 2018;61(3):101-13.

72. Haefliger JA. An angiotensin II-and NF-KB-dependent mechanism increases connexin 43 in murine arteries targeted by renin-dependent hypertension. Cardiovasc Res. 2010;87(1):166-76.

73. Siamantouras E, Price GW, Potter JA, Hills CE, Squires PE. Purinergic receptor (P2X7) activation reduces cell-cell adhesion between tubular epithelial cells of the proximal kidney. Nanomedicine. 2019:22:102-8.

74. Park JH, Kim YC. P2X7 receptor antagonists: a patent review (2010-2015). Expert Opin Ther Pat. 2017;27(3):257-67.

\section{Publisher's Note}

Springer Nature remains neutral with regard to jurisdictional claims in published maps and institutional affiliations.

Ready to submit your research? Choose BMC and benefit from:

- fast, convenient online submission

- thorough peer review by experienced researchers in your field

- rapid publication on acceptance

- support for research data, including large and complex data types

- gold Open Access which fosters wider collaboration and increased citations

- maximum visibility for your research: over $100 \mathrm{M}$ website views per year

At $\mathrm{BMC}$, research is always in progress.

Learn more biomedcentral.com/submissions 